\title{
Motor-functional profile of footballers of junior and cadet age
}

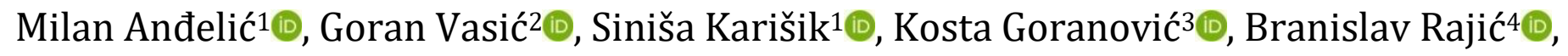 \\ Marko Joksimović5 ${ }^{[0}$
}

${ }^{1}$ Faculty of Physical Education and Sport, University of East Sarajevo, Bosnia and Herzegovina. ${ }^{2}$ Faculty of Sport and Physical Education, University of Novi Sad, Serbia. ${ }^{3}$ Faculty of Sports Management, University of Donja Gorica, Podgorica, Montenegro. ${ }^{4}$ Faculty of Physical Education and Sports, University of Valencia, Espana. ${ }^{5}$ Institute of Sports and Sports Medicine, Podgorica, Montenegro.

\begin{abstract}
Football is probably the most popular game around the world, having taken over the globe with 256 million registered players in 208 countries. The aim of the study was to determine the differences in motor and functional abilities between football players of junior and cadet age. The research included a sample of 39 football players of the Kicker Football Club from Kraljevo, divided into two subsamples: 20 football players of junior age of chronological age of $17 \pm 0.6$ years and 19 football players of cadet age of chronological age of $15 \pm 0.6$ years. The following tests were used to assess motor skills: Starting acceleration at $10 \mathrm{~m}$, Starting acceleration at $10 \mathrm{~m}$ flying start, maximum running speed during the test at $10 \mathrm{~m}$, maximum running speed during the test at $10 \mathrm{~m}$ flying start, Illinois Agility test, while the following tests were used to assess functional abilities: Maximum oxygen consumption and maximum heart rates. The results of the study indicate that statistically significant differences were recorded only in motor abilities. The emphasis on working with younger categories should be placed on the long-term development process, to enable better success in senior age.
\end{abstract}

Keywords. Angle of pinning, anthropological status, chronological and biological age.

\section{Introduction}

Football (soccer) is probably the most popular game around the world (Mirkovet al., 2010), which dominated the globe (Velebit, 2003), with 256 million registered players (Lazarević, et al., 2013) in 208 countries (Junge et al., 2002; Alghannam, 2013). Football is a very complex game that belongs to complex sports, characterized by complexes of simple or complex movements in terms of multiplayer cooperation, while on the other hand it is a very simple game available to the general population, children, older, younger populations who play football recreationally, but and for whom football is a job, which is why it is the most important sideline in the world (Ćeremidžić, 2013). Success in the football game depends on many dimensions of the psychosomatic status of the athlete's personality, such as: morphological, sociological and conative characteristics, motor, functional and cognitive abilities and motivation (Smajić et al., 2010). Modern football requires emotional stability, football intelligence, speed, explosiveness, coordination, endurance, mastered technique and tactical variants from football players (Đurašković et al., 2002). Football is a sport that belongs to the group of complex polystructural acyclic activities (Erceg et al., 2018), and defines it as a team sport where players must achieve high performance using primary motor and functional abilities, as well as technical and tactical skills (Impellizzers et al., 2004; Krespi et al., 2018). According to the physiological classification, football is an aerobic-anaerobic sport dominated by mixed energy processes (Dujmović, 2000), with alternating phases of high load, such as sprints, jumps, rapid change of place and direction of movement, with and without the ball, sudden stops, etc. Football is a game that requires strong, enduring football players with good motor and functional abilities (Joksimović, 2007), with a high level of maximum oxygen

冈 M. Joksimović, e-mail: nicifor007@outlook.com

Received: March 12, 2020 - Accepted: March 28, 2021 - Published: March 30, 2021

To Cite: Anđelić, M., Vasić, G., Karišik, S., Goranović, K., Rajić, B., Joksimović, M. (2021). Motor-functional profile of footballers of junior and cadet age. Turk J Kinesiol, 7(1), 31-38. DOI: 10.31459/turkjkin.894737 
consumption $\left(\mathrm{VO}_{2} \max \right)$ (Joksimović, 2017). Functional abilities are defined through the efficiency of aerobic and anaerobic mechanisms, ie. basic energy processes for endurance of the organism (Prskalo \& Sporiš, 2016). Aerobic capacity of athletes is the general ability of the neuromuscular system to train with a given intensity, longer than usual (Stojanović et al., 2006), which indicates the general degree of metabolic processes that occur in the human body and represents most of the total energy capacity . $\mathrm{VO}_{2} \max$ refers to the intensity of aerobic processes and represents the capacity of the organism to use the maximum amount of oxygen at a given moment (Ranković et al., 2010), which is expressed either in absolute mode in liters per minute $(\mathrm{l} / \mathrm{min})$ or in relative mode in milliliters per kilogram $\mathrm{ml} / \mathrm{kg} /$ min). An important segment of the anthropological space is the motor abilities on the basis of which information is obtained about the motor functioning of man and as such has an important role in achieving sports results (Pavlović et al., 2018). In order for a football player to be able to fulfill demanding tasks, it is necessary to have a quality motor structure with those motor abilities that give a certain advantage in the game (Smajić et al., 2008; Lolić et al., 2011), because abilities in football rely. to a multitude of components, including technical, tactical, mental, and physical skills (Stølen et al., 2005; Yemen et al., 2018). It is considered that a high level of motor skills is a basic prerequisite for efficient learning and performing new motor structures (Gardašević, et al., 2012). As some authors point out (Reilly et al., 2000; Pivovarniček et al., 2013), football players don't need to have exceptionally good motor skills, but they must have an appropriate level of all abilities. In accordance with the above, the aim of the research is to determine the differences in motor and functional abilities in football players of junior and cadet age.

\section{Methods}

\section{Study Participants}

The research included a sample of 39 football players from the Kicker Football Club from Kraljevo, divided into two subsamples. The first subsample 20 (51.3\%) consisted of football players of junior age of chronological age of $17 \pm 0.6$ years, while the second subsample of $19(48.7 \%)$ consisted of football players of cadet age of chronological age of $15 \pm 0.6$ years . As parasitic factors are avoided, the respondents were informed about the goal and planned measurement procedures, which is in line with the Declaration of Helsinki. The study was approved by the Ethical Committee of the Faculty of Physical Education and Sport, University of East Sarajevo (No: M-106/20, Date:01.04.2021). The experiment included football players of junior and cadet age who have been training for more than two years. The tested football players did not have any injuries of the locomotor system that would affect the measurement results.

\section{Study Organization}

In this research, two spaces of anthropological status (motor and functional abilities) were examined for a group of respondents of the same competitive specialization, divided into seven variables.

\section{Variables for determining and assessing motor skills:}

Starting acceleration at $10 \mathrm{~m}$ ( M10SU, s), starting acceleration at $10 \mathrm{~m}$ with flying start (M10SUL, s), maximum running speed during the test at $10 \mathrm{~m}$ (M10SS, $\mathrm{m} / \mathrm{s}$ ), maximum running speed during the test at $10 \mathrm{~m}$ flying start (M10LSS, m/s), Illinois Agility test (IAT, s).

Variables for determining and assessing functional abilities:

Maximum oxygen consumption $\left(\mathrm{VO}_{2} \mathrm{max}, \mathrm{ml} / \mathrm{kg} / \mathrm{min}\right)$, maximum heart rate (HRmax, rpm)

Testing of the starting acceleration and maximum speed was realized with photo cells Chrono Jump timing gates (BoscoSystem, Spain). The photo cells were placed at a distance of 10 meters. This distance was measured with a meter tape. For the start acceleration test, the subjects were in the space of one meter behind the first photocell with one foot in the stride, while for the assessment of the flying start, the subjects had a run of six meters. The test begins with the intersection of the air of the photocell at the start and ends with the intersection of the air of the photocell at the finish.

The Illinois Agility test is realized by placing four cones $10 \mathrm{~m}$ long and five meters wide. Two cones at one end $\mathrm{A}$ and $\mathrm{D}$ mark the beginning and end of the test where the photocells are placed. Cones B and C are at the other end. Four cones with a distance of 
three meters are placed in the middle. The subject is in the starting position lying on his chest with his elbows in the air and his head facing the starting line. At the given signal, the subject gets up as soon as possible and runs towards cone $B$. The measurement starts when the subject cuts the air of the photocell. From cone $\mathrm{B}$ the subject runs towards cone 1 and then runs zigzag between cones to the 4th cone and returns back to cone 1 , where he continues running to cone $C$, and from cone $C$ runs to cone $D$ where he ends by intersecting the rays of the photocell, figure 1 (Dawes \& Roozen, 2012). The measurement was performed with Chrono Jump timing gates photocells (BoscoSystem, Spain).

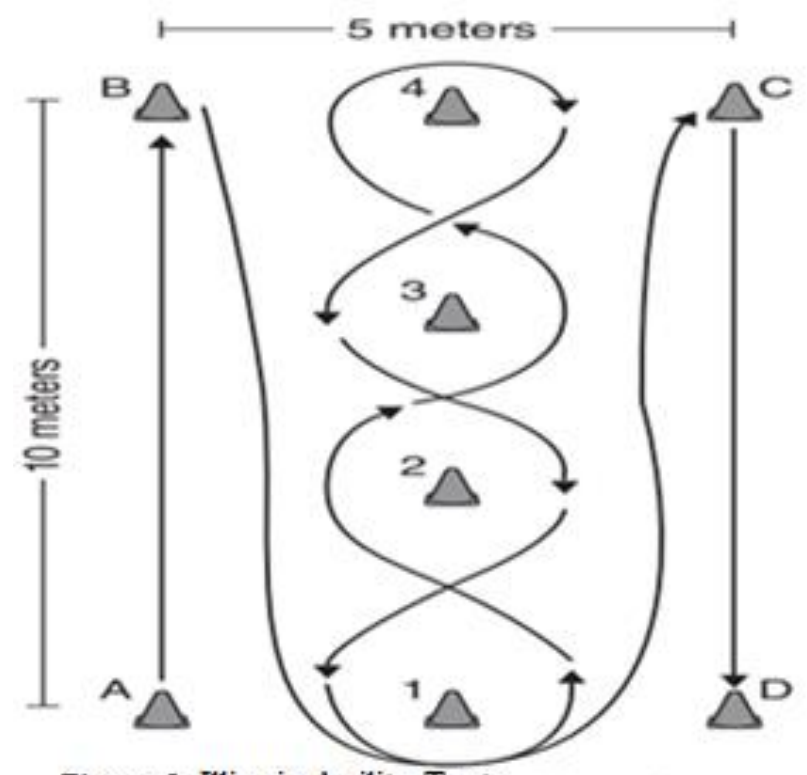

Figure 1. Illinois Agility Test

$\mathrm{VO}_{2}$ max expressed in $\mathrm{ml} / \mathrm{kg} / \mathrm{min}$ was indirectly determined via the Shuttle run test. The test belongs to field multi-stage progressive tests, which assess the aerobic power of the subjects (Radaković, 2016). Respondents run between two lines at a distance of 20 $\mathrm{m}$ at a pace dictated by an audible signal from a cassette player. At each sound signal the subject must be with both feet across the line. The goal of the test is for the respondent to run as many sections as possible. The initial speed is $8.0 \mathrm{~km} / \mathrm{h}$ and corresponds to a light run, and every minute the speed increases by $0.5 \mathrm{~km} / \mathrm{h}$ (Stojiljković et al., 2005). HRmax was measured immediately after completion of the Shuttel run test by palpation on the carotid artery. Pulse palpation is performed by placing the cheekbones of the second, third and fourth or at least the second and third fingers on the left or right catheter artery. The pulse is measured in a time of 10 seconds, the obtained value is multiplied by six which gives a pulse per minute.

\section{Statistical Analysis}

All data collected by the research were processed by descriptive and comparative statistics procedures. From the space of descriptive statistics, measures of central tendency and measures of dispersion were calculated for each variable. From the space of comparative statistics, a discriminant parametric procedure was used, analysis of variance with one factor (ANOVA) when quantifying the significance of differences within each variable. For all calculations, the application statistical program for personal computers SPSS (Statistical Package for the Social Sciences) for Windows - version 20.0 was used.

\section{Results}

Table 1 shows the basic descriptive parameters for football players of junior and cadet age. Junior football players had better results in functional tests. Thus, the average values of $\mathrm{VO}_{2} \max$ in juniors were $(48.02$ $\mathrm{ml} / \mathrm{kg} / \mathrm{min}$ ), in relation to football players of cadet age whose average values $(45.87 \mathrm{ml} / \mathrm{kg} / \mathrm{min})$ were Table 1. Also, the values of HRmax in juniors were (177.70 beat $/ \mathrm{min})$, while for cadets it was (180.11 rpm). When it comes to motor skills, where speed is tested, junior football players achieved better results in all variables.

The average values in juniors in the variable M10SU was $(1.73 \mathrm{~s})$, while in cadets the average time was $(1.79 \mathrm{~s})$. The average speed achieved by junior football players in the variable M10SS was $(5.77 \mathrm{~m} / \mathrm{s})$, while the average speed of football players of cadet age was $(5.57 \mathrm{~m} / \mathrm{s})$. In the variable M10SUL, the average values for football players of junior age were (1.42 s), while for football players of cadet age (1.46 s). The average speed achieved by football players of junior age in the variable M10LSS was $(7.04 \mathrm{~m} / \mathrm{s})$, while it was achieved by football players of cadet age $(6.82$ $\mathrm{m} / \mathrm{s}$ ). Junior football players also achieved better results in the IAT variable with an average time of $(16.00 \mathrm{~s})$, as opposed to cadet football players who achieved a time of (16.51 s). Table 2 shows the results of the analysis of variance with one factor - ANOVA, which was used to determine the differences between 
football players of junior and cadet age in motor and functional abilities. Analyzing Table 2, ANOVA univariate test results, statistically significant differences between groups were recorded in variables (IAT; M10SU; M10SS; M10SUL and M10LSS) with statistical significance of $p \leq 0.05, p \leq 0.01$, while in variables $\left(\mathrm{VO}_{2} \max ; \mathrm{HRmax}\right)$ no statistically significant differences were recorded.

\begin{tabular}{llcc}
$\begin{array}{l}\text { Table } 1 \\
\text { Descriptive statistics of footballers of junior and cadet age. }\end{array}$ \\
\hline \multicolumn{1}{l}{ Variables } & Age & Mean $\pm \mathrm{SD}$ & Range \\
\hline $\mathrm{VO}_{2 \max }(\mathrm{ml} / \mathrm{kg} / \mathrm{min})$ & Cadets & $45.87 \pm 6.12$ & $28.8-57-5$ \\
& Juniors & $48.02 \pm 3.93$ & $41.9-54.3$ \\
$\mathrm{HR}$ max $(\mathrm{bpm})$ & Cadets & $180.11 \pm 15.51$ & $162-222$ \\
& Juniors & $177.79 \pm 17.19$ & $142-216$ \\
$\mathrm{IAT}(\mathrm{s})$ & Cadets & $16.51 \pm 0.54$ & $15.38-17.41$ \\
& Juniors & $16.00 \pm 0.44$ & $15.15-16.81$ \\
$\mathrm{M} 10 \mathrm{SU}(\mathrm{s})$ & Cadets & $1.79 \pm 0.10$ & $1.62-2.03$ \\
& Juniors & $1.73 \pm 0.09$ & $1.54-1.86$ \\
$\mathrm{M} 10 \mathrm{SS}(\mathrm{m} / \mathrm{s})$ & Cadets & $5.57 \pm 0.30$ & $4.93-6.16$ \\
& Juniors & $5.77 \pm 0.31$ & $5.37-6.48$ \\
$\mathrm{M} 10 \mathrm{SUL}(\mathrm{s})$ & Cadets & $1.46 \pm 0.06$ & $1.36-1.57$ \\
& Juniors & $1.42 \pm 0.07$ & $1.27-1.52$ \\
$\mathrm{M} 10 \mathrm{LSS}(\mathrm{m} / \mathrm{s})$ & Cadets & $6.82 \pm 0.29$ & $6.37-7.37$ \\
& Juniors & $7.04 \pm 0.36$ & $6.57-7.86$ \\
\hline
\end{tabular}

\section{Table 2}

Differences in motor and functional abilities of footballers of different age.

\begin{tabular}{|c|c|c|c|c|}
\hline Variables & Age & Mean $\pm S D$ & $\mathrm{~F}$ & $p$ \\
\hline \multirow[t]{2}{*}{$\mathrm{VO}_{2 \max }(\mathrm{ml} / \mathrm{kg} / \mathrm{min})$} & Cadets & $45.87 \pm 6.12$ & 1.712 & .199 \\
\hline & Juniors & $48.02 \pm 3.93$ & & \\
\hline \multirow[t]{2}{*}{$\mathrm{HR}_{\max }(\mathrm{bpm})$} & Cadets & $180.11 \pm 15.51$ & .198 & .659 \\
\hline & Juniors & $177.79 \pm 17.19$ & & \\
\hline \multirow[t]{2}{*}{ IAT (s) } & Cadets & $16.51 \pm 0.54$ & 10.648 & $.002 * *$ \\
\hline & Juniors & $16.00 \pm 0.44$ & & \\
\hline \multirow[t]{2}{*}{ M10SU (s) } & Cadets & $1.79 \pm 0.10$ & 4.204 & $.047^{*}$ \\
\hline & Juniors & $1.73 \pm 0.09$ & & \\
\hline \multirow[t]{2}{*}{ M10SS (m/s) } & Cadets & $5.57 \pm 0.30$ & 4.121 & $.050 *$ \\
\hline & Juniors & $5.77 \pm 0.31$ & & \\
\hline \multirow[t]{2}{*}{ M10SUL (s) } & Cadets & $1.46 \pm 0.06$ & 4.249 & $.046^{*}$ \\
\hline & Juniors & $1.42 \pm 0.07$ & & \\
\hline \multirow[t]{2}{*}{ M10LSS (m/s) } & Cadets & $6.82 \pm 0.29$ & 4.309 & $.045^{*}$ \\
\hline & Juniors & $7.04 \pm 0.36$ & & \\
\hline
\end{tabular}




\section{Discussion}

Football today is a very demanding game in which players are exposed to numerous actions that require strength, speed, agility, balance, stability, flexibility as well as an adequate level of endurance (Bloomfield et al., 2007; Jovanović et al., 2011). Sports games (football) are characterized by fast actions, where athletes need to make quick decisions and solve specific tasks that occur during the game. Based on that, it can be concluded that reaction speed, acceleration, maximum speed and agility are the basic components in sports games (Šimonek et al., 2017). Drid, (2012) points out that the reaction rate is a consequence of a standard or complex signal and that the response largely depends on the ability to anticipate. Maximum speed and acceleration are important traits in team sports, while running speed over short distances is key to success (Köklü, 2015). Acceleration plays an important role in football, where the footballer must develop as much body acceleration as possible in a shorter time (Drid, 2012). Agility is one of the main abilities in football (Little \& Williams, 2005), which maintains and controls proper body position while it changes direction rapidly through a series of movements (Yap et al., 2000), which depends on strength, reaction time, movement speed, and muscle coordination. A quick start, stop and quick changes of direction are essential for footballers (Nebhendra, 2010; Chandrasekaran, 2012). Statistically significant differences were found between football players of junior and cadet age in tests of speed (M10SU, $p<0.04$; M10SS, $p<0.05$, M10SUL; $p<0.04$, M10LSS, $\mathrm{p}<0.04$ ) and agility (IAT, $p$ $<0.01$ ). However, it should be taken into account that the nature of agility movements is closely related to speed (Chaleh et al., 2012), which has been confirmed in many studies. Reilli et al. (2000) state that football players do not have to have good motor skills, however, they must have an appropriately high level in all abilities (Pivovarniček et al., 2013). Research conducted by Nedeljković et al. (2011) found that there are statistically significant differences between football players of the cadet age of FC Vojvodina and members of the Serbian national team in the $10 \mathrm{~m}$ run. Kaplan et al. (2009) found statistically significant differences between professional and amateur football players in speed and agility. The average time achieved by juniors in the variable M10SU is $1.73 \mathrm{~s}$, while in cadets the time was $1.79 \mathrm{~s}$, while in the variable IAT juniors achieved time of $16.00 \mathrm{~s}$, and cadets $16.51 \mathrm{~s}$. Identical results for the starting acceleration were obtained by Tomaš et al. (2014) on a sample of $\mathrm{N}=22$ - U16 football players from the Czech Republic, where they recorded an average time for the starting acceleration of $1.85 \mathrm{~s}$. Young FC Rangers U17 players achieved a time of $1.79 \mathrm{~s}$, while cadets achieved a time of $1.81 \mathrm{~s}$ in the same variable (McKenna, 2010). Italian U18 players achieved a time of $1.77 \mathrm{~s}$ in the $10 \mathrm{~m}$ run (Bravo et al., 2007). Highspeed actions in football can be categorized as actions that require acceleration, maximum speed, or agility (Gambetta, 1996). The average time achieved by football players of junior age in the variable M10SUL is $1.42 \mathrm{~s}$, while that of football players of cadet age was $1.46 \mathrm{~s}$. Better results in junior football players are the cause of factors that are mediated by growth and maturation (Tomaš et al., 2014). The speed of the sprint depends on the age and position in the team, in young football players (Al Haddad et al., 2015; Mendez-Villanueva, \& Sar., 2011), so it can be expected that older football players will achieve higher speed (Al Haddad et al., 2015). The average sprint speed achieved by junior football players in the variables M10SS and M10LSS was $5.77 \mathrm{~m} / \mathrm{s}$ and 7.04 $\mathrm{m} / \mathrm{s}$, respectively, while the cadet age football players achieved a speed of $5.57 \mathrm{~m} / \mathrm{s}$ and $6.82 \mathrm{~m} / \mathrm{s}$, respectively. Similar results were obtained by Manzer et al. (2016) on a sample of $n=8$ athletes aged 17 years and in $=8$ athletes aged 19 years, where they recorded an average sprint speed time of $9.2 \mathrm{~m} / \mathrm{s}$ and $8.0 \mathrm{~m} / \mathrm{s}$ for $10 \mathrm{~m}$ running. Also, Vescovi et al. (2011) recorded a running speed of $6.84 \mathrm{~m} \mathrm{/} \mathrm{s} \mathrm{for} \mathrm{U15}$ football players, while they recorded a running speed of $7.01 \mathrm{~m} / \mathrm{s}$ for U16 football players. Loturco et al. (2014) state that the time achieved by U18 football players in the 10 -meter run is $5.4 \mathrm{~m} / \mathrm{s}$. Running speed and acceleration are two different components of sprint and many researchers believe that they are determined by a combination of specific physiological, metabolic, biomechanical and morphological factors (Buchheit et al., 2014). Football is a sport that is predominantly of the aerobic type, where one of the determinants of success is aerobic endurance, also called $\mathrm{VO}_{2} \max$ (Pelemiš et al., 2018). $\mathrm{VO}_{2} \max$ is the ability of an athlete to enter a certain amount of oxygen through the respiratory system, to deliver it to the cardiovascular system and use that oxygen in skeletal muscle (Haff \& Triplett, 2016). Higher oxygen intake allows higher production of ATP through aerobic metabolic processes. Thus, $\mathrm{VO}_{2} \mathrm{max}$ is an indicator of the athlete's ability to continue exercising over a longer period (Abernethy et al., 2012) and 
mostly depends on the degree of training, but also on gender, age, body constitution, etc. (Čutović et al., 2018). $\mathrm{VO}_{2}$ max in children, unlike adults, is largely influenced not only by physiological, but also by anthropometric components that change during development. In boys, $\mathrm{VO}_{2} \max$ develops from the prepubertal period and gradually develops to maturity. At the end of puberty in boys, $\mathrm{VO}_{2} \max$ monitors physical development, which increases annually by about $1 \mathrm{ml} / \mathrm{kg} / \mathrm{min}$ (Živanić et al., 1999). Research assessing $\mathrm{VO}_{2}$ max in young football players indicates that young people have a lower level compared to seniors and it is about $60 \mathrm{ml} / \mathrm{kg} / \mathrm{min}$ (Stolen et al., 2005). Statistically significant differences between junior and cadet football players in $\mathrm{VO}_{2} \mathrm{max}$ and HRmax were not recorded, however, junior football players achieved better average time in the variable $\mathrm{VO}_{2}$ max and HRmax. Similar studies were conducted (Stanković et al., 2007) who recorded an average time of $53.02 \mathrm{ml} / \mathrm{kg} / \mathrm{min}$ and 23 junior football players with VO2max values of 52.19 $\mathrm{ml} / \mathrm{kg} / \mathrm{min}$ in a sample of 22 cadet football players. The reason for the better results of football players of cadet age, the authors state, is that it is the result of better selection in certain years as well as better work at a certain age. Metaxas et al., (2014) recorded average values of $\mathrm{VO}_{2} \max$ and HRmax in younger pioneers $\mathrm{n}=13,56.37 \mathrm{ml} / \mathrm{kg} / \mathrm{min}$ and $196.2 \mathrm{rpm}$, in pioneers $\mathrm{n}=10,58.20 \mathrm{ml} / \mathrm{kg} / \mathrm{min}$ and 200.5 beat $/ \mathrm{min}$, while in cadets $\mathrm{n}=9$, they recorded values of $58.51 \mathrm{ml} \mathrm{/} \mathrm{kg} \mathrm{/} \mathrm{min} \mathrm{and} 197 \mathrm{rpm}$. Veljović \& Stojanović, (2013) recorded V02max values of 44.3 $\mathrm{ml} / \mathrm{kg} / \mathrm{min}$ in football players of pioneer, cadet and junior age; $50.1 \mathrm{ml} / \mathrm{kg} / \mathrm{min} ; 51.3 \mathrm{ml} / \mathrm{kg} / \mathrm{min}$. Ponorac et al. (2005) determined differences in $\mathrm{VO}_{2} \max$ between athletes of different sports (judo, football and rowing). The best results were achieved by rowers $55.8 \mathrm{ml} / \mathrm{kg} / \mathrm{min}$, football players $53.6 \mathrm{ml} / \mathrm{kg} / \mathrm{min}$, judokas $47.2 \mathrm{ml} / \mathrm{kg} / \mathrm{min}$. Helgerud et al. (2001) point out that the values of $\mathrm{VO}_{2}$ max in the young representatives of Hungary are between 64.3 and 73.9 $\mathrm{ml} / \mathrm{kg} / \mathrm{min}$. Ostojić et al. (2003) found that football players of the first league of Serbia and Montenegro have higher values of $\mathrm{VO}_{2} \max 53.8 \mathrm{ml} / \mathrm{kg} / \mathrm{min}$, compared to amateur football players 44.8 $\mathrm{ml} / \mathrm{kg} / \mathrm{min}$.

\section{Conclusion}

Modern football training places great demands on young football players, who must be continuous in the training process in order to reach their maximum, then when it is most expected - in senior age. In order to establish a motor-functional profile in young football players, it is necessary to consider various factors, namely: chronological and biological age, years of training, morphology, and position in the game. The chronological age, calculated from the date of birth, is used in sports to form teams, identify talents and set limits for prescribed exercises. However, research has clearly shown that individuals of the same chronological age differ significantly from biological age, which refers to progression to a mature state and differs between different body systems. Motor-functional abilities should be checked frequently as feedback on training levels and assistance in player selection. A crucial problem for the selection of football players is the entry of children into puberty, due to the fact that children in this period progress in all segments of anthropological status. Therefore, the period of entering puberty as well as the pace of maturation is different, so coaches must accept the layered process of discovering talent. Therefore, emphasis should be placed on the longterm development process, in order to enable better success in senior age. It is essential that coaches who work with young football players recognize the needs of children and adolescents, as well as monitor the impact of biological maturation on football players' abilities and development in relation to programmed exercise. Finally, in top football, the training process requires the maximum application of science in order to be able to apply in practice and reduce the gap between science and practice.

\section{References}

Abernethy, B., Hanrahan, J. S., Kipers, V., Mackinnon, T. L., \& Pandy, G. M. (2012). Biofizičke Osnove Ljudskog Pokreta. Beograd. [In Serbian]. Datastatus.

Al Haddad, H., Simpson, B. M., Buchheit, M., Di Salvo, V., \& Mendez-Vilanueva, A. (2015). Peak match speed and maximal sprinting speed in young soccer players: Effect of age and playing position. International Journal of Sports Physiology and Performance, 10, 888-896.

Alghannam, A. F. (2013). Physiology of Soccer: The Role of Nutrition in Performance. J Nov Physiother, S3, 003.

Bloomfield, J., Polman, R., \& O'Donoghue, P. (2007). Physical demands of different positions in FA premier league soccer. J Sports Sci Med, 6, 63-70 
Bravo, F. D., Impellizzeri, F. M., Rampinini, E., Castagna, C., Bishop, D., \& Wisløff, U. (2007) Sprint vs. interval football. Int J Sports Med, 29, 668-674.

Buchheit, M., Samozino, P., Glynn, J. A., Simpson M. B., Al Haddad, H., Mendez-Villanueva, A., \& Morin, B.J. (2014). Mechanical determinants of acceleration and maximal sprinting speed in highly trained young soccer players. Journal of Sports Sciences, 32(20), 1-8.

Chaleh, C. M., Fatemi, R., \& Shahsavar, A. (2012). Relationship between speed, agility and anaerobic power of 14-16 years elite soccer players. International Research Journal of Applied and Basic Sciences, 3(2), 472432.

Chandrasekaran, S., Anbanandan, A., Krishnaswamy, S., \& Balakrishnan, A. (2012). A study of selective motor fitness components empowers on playing ability among low a high performers of state level football players. International Multidisciplinary Research Journal, 2(3), 54-60.

Čutović, M., Bajić, G., \& Vuković-Dejanović, V. (2018). Aerobni kapacitet značaj $\mathrm{VO}_{2 \max }$ kod sportista u uslovima opterećenja visokog intenziteta. [In Serbian]. Osma međunarodna konferencija "Sportske Nauke i Zdravlje", 33-44.

Ćeremidžić, D. (2013). Fudbal. [In Serbian]. Fakultet fizičkog vaspitanja i sport.

Drid, P. (2012). Teorija Sportskog Treninga. [In Serbian]. Fakultet sporta i fizičkog vaspitanja.

Dujmović, P. (2000). Škola Nogometa. [In Serbian]. Hrvatski Nogometni Savez.

Dawes, J., \& Roozen. M. (2012). Developing agility and quickness. NSCA, Human Kinetics.

Đurašković, R., Radovanović, D. \& Joksimović, A. (2002). Uporedni kriterijumi antropometrijskih, funkcionalnih i motoričkih varijabli u selekciji fudbalera mlađih kategorija. [In Serbian]. Godišnjak Fakulteta Sporta i Fizičkog Vaspitanja, (11), 125-131.

Haff, G. G., \& Triplett, N. T. (2016). Essentials of strength training and conditioning. (Fourth Edition). NSCA. Human Kinetics.

Helgerud, J., Engen, L. C., Wisloff, U., \& Hoff, J. (2001). Aerobic endurance training improves soccer performance. Med Sci Sports Exerc, 33(11), 1925-1931.

Impellizzeri, F. M., Rampinini, E., Coutts, A. J., Sassi, A. \& Marcora, S. M. (2004). Use of RPE- ased training load in soccer. Medicine \& Science in Sports \& Exercise, 36(6), 1042-1047.

Jemni, M., Prince, S. M., \& Baker, J. S. (2018). Assessing cardiorespiratory fitness of soccer players: Is test specificity the issue? - A Review. Sports Medicine, 4, 28

Joksimović, A. (2007). Fudbal- Tehika i Metodika. [In Serbian]. GIP "Timok".
Joksimović, M. (2017). Sportska Forma Sportiste. (Diplomski rad). [In Serbian]. Fakultet fizičkog vaspitanja i sport

Jovanovic, M., Sporis, G., Omrcen, D., \& Fiorentini, F. (2011). Effects of speed, agility, quickness training method on power performance in elite soccer players. J Strength Cond Res, 25(5), 1285-1292

Junge, A., Rosch, D., Peterson, L., Graf-Baumann, T., \& Dvorak, J. (2002). Prevention of soccer injuries: a prospective intervention study in youth amateur players. Am J Sports Med, 30, 652-659.

Kaplan, T., Erkmen, N., \& Taskin, H. (2009). The evaluation of the running speed and agility performance in professional and amateur soccer players. J Strength Cond Res, 23(3), 774-778.

Köklü, Y., Alemdaro glu, U., Özkan, A., Koz, M., \& Ersöz, G. (2015). The relationship between sprint ability, agility, and vertical jump performance in young soccer players. Science \& Sport, 30, 1-5.

Krespi, M., Sporiš, G. \& Mandić-Jelaska, P. (2018). Effects of Two Different Taperin Protocols on Fitness and Body Composition in Young Soccer Players: Positiona Differences. Acta Kinesiologica, 12 (1), 62-71.

Lazarević, P., Živković, V., \& Vuković, S. (2013). Uticaj šestomesečnog trenažnog programa na morfofunkcionalne parameter mladih fudbalera. [In Serbian]. Racionalna Terapija, 5(1), 31-33.

Little, T., \& Williams, A. (2005). Specificity of acceleration, maximum speed and agilitiy in professional soccer players. In: Reilly, T., Cabri, J., \& Araujo, D. Science and Football. Routledge, Taylor \& Francis.

Little, T., \& Williams, A. G. (2005). Specificity of acceleration, maximum speed and agility in professional soccer players. J Strength Cond Res, 19(1), 76-78.

Lolić, V., Bajrić, O., \& Lolić, D. (2011). Struktura motoričkog prostora fudbalera kadetskog uzrasta. [In Serbian]. Sportske nauke i zdravlje, 1(1), 152-156.

Loturco, I., Kobal, R., Gil, S., Pivetti, B., Kitamura, K., Pereira, L. A., Abad, C. C. C., Nakamura, F. Y. (2014). Differences in loaded and unloaded vertical jumping ability and sprinting performance between Brazilian elite under-20 and senior soccer players. American Journal of Sports Science, 2(6-1), 8-13.

Manzer, S., Mattes, K., \& Hollander, K. (2016). Kinematic analysis of sprinting pickup acceleration versus maximum sprinting speed. Biology of Exercise, 12(2), 5567.

McKenna, M. (2010). Methods of identifying high velocity groeth in youth soccer players. Thesis, University of Glasgow, Glasgow. Retrieved from http://theses.gla.ac.uk/2078/01/2010mckennamsc.pdf

Mendez-Villanueva, A., Buchheit, M., Kuitunen, S., Douglas, A., Peltola, E., \& Bourdon, P. (2011). Age-related differences in acceleration, maximum running speed, 
and repeated-sprint performance in young soccer players. J Sports Sci, 29, 477-484.

Metaxas, T. I., Mandroukas, A., Vamvajoudis, E., Kotoglou, K., Ekblom, B., \& Mandroukas, K. (2014). Muscle Fiber Characteristics, Satellite Cells and Soccer Performance in Young Athletes. Journal of Sports Science ana Medicine, 13, 493-501.

Mirkov, M. D., Kukolj, M., Ugarković, D., Koprivica, J. V., \& Jarić, S. (2010). Development of Anthropometricand Physical Performance Profiles of Young Elite Male Soccer Players: A Longitudinal Study. J Strength Cond Res, 24(10), 2677-2682.

Nabhendra, S. (2010). A Comparative Study of Motor Performance Level among Categorized Skilled Hockey Players. International Journal of Educational Administration, 2(2), 403-410

Nedeljkov, N., Smajic, M., Molnar, S., \& Tomic, B. (2011). Differences in explosive strength of legs of footballers of cadet categories. Sport Mont, IX(31-32-33), 103-109.

Ostojić, S., Mazić, S., Dikić, N., \& Velkovski, S. (2003). Physiological profile of elite serbian soccer players. Abstract book. Risk factors and health: From molecule to the scientific basis of prevention. Zrenjanin.

Pavlović, R., Joksimović, M., \& Simeonov, A. (2018). Differences in morphological, motor and functional parameters of students. International Journal of Fitness, Health, Physical Education \& Iron Games. 5(2), 1-8.

Pelemiš, V., Ujsasi, D., Džinović, D., \& Josić, D. (2018). Relacije morfoloških karakteristika i aerobne izdržljivosti fudbalera različitih uzrasnih kategorija. [In Serbian]. Sportske Nauke i Zdravlje, 8(1), 77-85.

Pivovarniček, P., Martin Pupiš, M., Tonhauserová, Z., \& Tokárová, M. (2013). Nivo sprinterskih sposobnosti, eksplozivne snage i specijalne izdržljivosti vrhunskih mladih fudbalera na različitim pozicijama. [In Serbian]. SportLogia, 9(2), 186-200.

Ponorac, N., Matavulj, A., Grujić, N., Rajkovača, Z., \& Kovačević, P. (2005). Maksimalna Potrošnja Kiseonika (V02max) kao Pokazatelj Fizičke Sposobnosti Sportiste. Acta Medica Medianae, 44(4), 17-20.

Prskalo, I., \& Sporiš, G. (2016). Kineziologija. [In Serbian]. Kineziološki Fakultet.

Radaković, R. (2016). Relacije motoričke, funkcionalne $i$ metaboličke pripremljenosti sa takmičarskom performansom vrhunskih fudbalera merenom metodom softverske analize kretanja "trackin motion". [In Serbian]. (Doktorska disertacija). Beograd. Fakultet za sport i fizičko vaspitanje.
Ranković, G. Mutavdžić, V., Toskić, D., Preljević, A., Kocić, M., Nedin-Ranković, G., \& Damjanović, N. (2010). Aerobic Capacity as an Indicator in Different Kinds of Sports. Bosn J Basic Med Sci, 10(1), 44-48.

Reilly, T., Bangsbo, J., Franks, A. A. (2000). Anthropometric and physiological predispositions for elite soccer. Journal of Sport Sciences, 18, 669-683.

Smajić, M., Molnar, S. \& Popović, S. (2010). Longitudinalna dimenzionalnost skeleta mladih fudbalera. [In Serbian]. Glasnik Antropološkog Društva Srbije, (45), 237-242.

Smajić, M., Radoman, M., \& Molnar, S. (2008). Struktura bazično motoričkih sposobnosti fudbalera uzrasta 10-12 godina. Sport Mont, 6(15,16,17), 553-556.

Stanković, A., Demir, M., \& Hadžiahmetović, N. (2007). Vsftest i stanje funkcionalnih sposobnosti kod nogometaša pionirske, kadetske i juniorske selekcije. [In Serbian]. Acta Kinesiologica, 1(1), 64-68.

Stojanović, T., Kostić, R., \& Ahmetović, Z. (2006). Teorija $i$ Metodika Sportskog Treniga. [In Serbian]. Fakultet za sport i turizam.

Stojiljković, S., Mitić, D., Mandarić, S., \& Nešić, D. (2005). Fitness. [In Serbian]. Beograd, FSFV.

Stølen, T., Chamari K., Castagna, C., \& Wisløff, U. (2005). Physiology of soccer, an update. Sports Medicine, 35, 501-536.

Šimonek, J., Horička, P., \& Hianik, J. (2017). The differences in acceleration, maximal speed and agility between soccer, basketball, volleyball and handball players. Journal of Human Sport and Exercise, 12(1), 73-82.

Tomaš, M., František, Z., Lucia, M., \& Jaroslav, T. (2014). Profile, Correlation and Structure of Speed in Youth Elite Soccer Players. Journal of Human Kinetics, 40, 149-159.

Velebit, R. (2003). Savremeni Fudbalski Trening. [In Serbian]. Sportska Akademija.

Veljović, D., \& Stojanović, M. (2013). Morfo-funkcionalne karakteristike mladih fudbalera. TIMS Acta, 3, 35-41.

Vescovi, J., Ruph, R., Brown, T. D., \& Marques, C. M. (2011). Physical Performance characteristics of high-level female soccer players 12-21 years of age. Scan J of Med and Sci in Sports, 21(5), 670-670.

Yap, W., Brown, L. E., \& Woodman, G. (2000). Development of Speed, Agility, and Quickness for the Female Soccer Athlete. NSCA, 20(1), 9-12.

Živanić, S., Životić, V. M., Mijić, R., \& Dragojević, R. (1999). Aerobna sposobnost i njena procena Astrandovim testom opterećenja na biciklergometru. [In Serbian]. Udruženje za medicinu sporta Srbije. 